\title{
On the Sexuality and Development of the Ascocarp in Lachnea stercorea, Pers.
}

\author{
BY
}

\author{
H. C. I. FRASER, B.Sc., F.L.S. \\ Assistant Lecturer in Botany, Royal Holloway College, University of Londors.
}

\section{With Plates $\mathbf{X X I X}$ and $\mathbf{X X X}$.}

$\mathrm{T}$ HE recent discovery in Humaria gramulata (Blackman and Fraser (4)) of a reduced type of fertilization, brought about by the fusion in pairs of the nuclei of the female coenogamete, rendered advisable the investigation of other related forms with a view to ascertaining whether such a process be of common occurrence.

Various Discomycetes, growing on wood and on dung, were therefore examined, and a well-developed ascogonium was found in Lachnea stercorea.

Lachnea stercorea, Pers. (= Peziza stercorea, Pers.), is a small orange Discomycete, occurring during the winter and spring on cow-dung. It is about $4 \mathrm{~mm}$. in diameter, and is furnished with numerous long hairs. The material used was always allowed to develop upon its natural substratum, as in view of the conflicting results obtained by Harper (17) and Dangeard (8) on Pyronema confuens, it seemed wiser to avoid any unnatural conditions in dealing with a case of doubtful or reduced sexuality.

Methods. Material was fixed in chromacetic acid and in various strengths of Flemming's fluid, Flemming's weaker fluid, diluted with an equal volume of water, being found the most satisfactory. Sections were usually cut $5 \mu$ in thickness, and were stained either with Flemming's triple stain or with Heidenhain's iron haematoxylin, followed by eosin. This stain proved very successful. The slide after treatment with haematoxylin was covered with a fairly strong solution of eosin in clove oil, which was washed off after a few seconds with clove oil, followed by cedar oil. The cell walls of the ascocarp were by these means stained bright red, and the definition of the nuclei was also enhanced. Preparations mounted in Canada Balsam sometimes faded rapidly, but they kept well in Damar Lac or in Gumthus.

[Annals of Botany, Vo1. XXI. No. LXXXIII. July, 1907.] 


\section{Germination of the Spores.}

The spores were placed in various fluids at a temperature of about $15^{\circ} \mathrm{C}$., but without result. In nature the spores probably pass through the body of the cow, and an attempt was therefore made to imitate normal digestion; spores were placed successively in saliva, in gastric juice (a few drops of liquor pepticus of Benger in 0.2 per cent. aqueous solution of hydrochloric acid), in pancreatic juice (one part of Benger's liquor pancreaticus to two parts of I per cent. aqueous solution of sodium carbonate), and in watery extract of cow-dung. The spores were left in each of the first three fluids for 3-4 hours, and in the dung extract for considerably longer, at a temperature of $38^{\circ} \mathrm{C}$. They were then transferred in dung extract to slides, where they were allowed to cool gradually. The spores, which, before treatment, appeared thick-walled and hyaline (Fig. I $a$ ), showed an increase in size, thin walls, granular contents, and one or two large vacuoles (Fig. I $b$ ). Later the vacuoles became more numerous, and the spores still larger, and, about two days after the beginning of the experiment, germinations were observed, a germ-tube passing out from each end of the spore.

In order to ascertain which of the fluids used was effective in germination, they were now employed separately, and spores were placed in dung extract at a temperature of $38^{\circ} \mathrm{C}$. for several hours and then mounted as before. Germinations took place, the mycelium being, in certain cases, well developed and showing branches (Fig. I $c$ ). Spores placed in distilled water, but otherwise treated exactly like those in dung extract, did not show even the changes in size and contents preliminary to germination.

The alkalinity of a sample of dung extract was now ascertained, and it was found to be approximately that of a centinormal solution. Spores were placed, therefore, in decinormal and in centinormal solutions of sodium carbonate, and in a solution half the strength of the latter $\left(\frac{\mathrm{N}}{200}\right)$. They were kept for about $3 \circ$ hours at $38^{\circ} \mathrm{C}$, and then mounted and allowed to cool. The spores in the $\frac{\mathrm{N}}{\mathrm{IO}}$ solution were somewhat shrunken and distorted, no doubt by plasmolysis, and showed no further changes. In the other two solutions they were thin walled and vacuolate. After various attempts had been made, germinations were obtained in a $\frac{\mathrm{N}}{\mathrm{IOO}}$ solution, but they were rare, owing, probably, to lack of food-material, and, in more than one case, the germ-tubes from a spore germinating in the ascus were found running in the epiplasm, and no doubt obtaining nourishment from it. (Fig. 2.) 
The results of these and other experiments are tabulated below :-

\begin{tabular}{|c|c|c|c|c|c|}
\hline $\begin{array}{l}\text { No. of } \\
\text { Expt. }\end{array}$ & Medium. & Temp. & Time. & $\begin{array}{l}\text { Subsequent } \\
\text { Treatment. }\end{array}$ & Result. \\
\hline I (A) & Full digestion & $3^{8^{\circ} \mathrm{C}}$. & I 8 hrs. & $\begin{array}{l}\text { Mounted in } \\
\text { dung extract } \\
\text { at } 25^{\circ} \mathrm{C} \text {. and } \\
\text { cooled slowly. }\end{array}$ & $\begin{array}{l}\text { Germination } \\
\text { 51 hrs. after } \\
\text { expt.began. }\end{array}$ \\
\hline $2(\mathrm{~B})$ & $"$ & " & $"$ & $"$ & $\begin{array}{l}\text { Preliminary } \\
\text { changes. }\end{array}$ \\
\hline $3(\mathrm{C})$ & Dung extract & " & $2 \mathrm{I} \mathrm{hrs.}$ & $"$ & $\begin{array}{l}\text { Germination } \\
5 \circ \frac{1}{2} \text { hrs. after } \\
\text { expt. began. }\end{array}$ \\
\hline $4(X)$ & Distilled water & $"$ & $40 \frac{1}{2} \mathrm{hrs}$. & $\begin{array}{l}\text { Mounted in } \\
\text { water; treated } \\
\text { as above. }\end{array}$ & No changes. \\
\hline $5(Y)$ & Dung extract & " & $4 \mathrm{c} \frac{1}{2} \mathrm{hrs}$. & $\begin{array}{l}\text { Mounted in ex- } \\
\text { tract; treated } \\
\text { as above. }\end{array}$ & $\begin{array}{l}\text { Germination } \\
\text { after } 49 \frac{1}{2} \text { hrs. }\end{array}$ \\
\hline 6 & $\frac{\mathrm{N}}{\mathrm{IO}} \mathrm{Na}_{2} \mathrm{Co}_{3}$ & " & 3I hrs. & $\begin{array}{l}\text { Mounted in solu- } \\
\text { tion used; treat- } \\
\text { ed as above. }\end{array}$ & $\begin{array}{l}\text { Spores } \\
\text { distorted. }\end{array}$ \\
\hline 7 & $\frac{\mathrm{N}}{\mathrm{I} 00}$, & " & $"$ & $"$ & $\begin{array}{l}\text { Preliminary } \\
\text { changes. }\end{array}$ \\
\hline 8 & $\frac{\mathrm{N}}{200} "$ & $"$ & $"$ & ", & " \\
\hline $9(\mathrm{I})$ & $\frac{\mathrm{N}}{100} "$ & $"$ & $3^{6} \mathrm{hrs}$. & $\begin{array}{l}\text { Mounted in solu- } \\
\text { tion at } 5^{\circ} \mathrm{C} \text { - } \\
\text { and cooled. }\end{array}$ & $\begin{array}{l}\text { Germination } \\
\text { after I } 33 \text { hrs. }\end{array}$ \\
\hline IO (II) & $" \quad "$ & $"$ & " & $\begin{array}{l}\text { Mounted in solu- } \\
\text { tion at } 25^{\circ} \mathrm{C} \text {. } \\
\text { and cooled. }\end{array}$ & $\begin{array}{l}\text { Germination } \\
\text { after } 18 \mathbf{1} \frac{1}{2} \\
\text { hrs. }\end{array}$ \\
\hline I I (III) & $\frac{N}{200} \quad$ & $"$ & " & $"$ & $\begin{array}{l}\text { Preliminary } \\
\text { changes }\end{array}$ \\
\hline 12 (IV) & Dung extract & , & , & ” & $"$ \\
\hline
\end{tabular}

It is noticeable that, treated with the digestive fluids or with dung extract, the spores germinated in every case approximately fifty hours after the beginning of the experiment, and it is probable that they do so in nature about two days after being swallowed by the animal. Germination would appear to be brought about by the combined influence of warmth and an alkaline medium, the action of which, in part at least, is to cause softening of the wall of the spore. 


\section{Vegetative MYCELIUM.}

The cells of the mycelium are multinucleate (Fig. 3) and show numerous conspicuous granules, often aggregated on the transverse walls, and corresponding, no doubt, to those observed in several other members of the Pezizineae. No organs of reproduction other than the ascocarps were observed in this form.

\section{Development of the Apothecium.}

The $\operatorname{archicarp}^{1}$ arises as a side branch from a vegetative hypha (Fig. 4), and becomes divided into two, then three (Fig. 5), and finally five or more cells. The terminal cell or ascogonium is oval in shape and larger than the others, and, as development proceeds, it becomes filled with dense contents. In cut and stained preparations it is seen to contain numerous nuclei; the cytoplasm is finely granular and shows a number of small, rounded vacuoles (Fig. 6).

Hyphae grow out from the lower cells of the archicarp and from the branch which bears it, and form a dense weft, above which the ascogonium rises.

So far the archicarp resembles that described by Woronin (22) for Lachnea scutellata, Gill. (= Peziza scutellata, L.), where a large, oval ascogonium, with granular, somewhat vacuolate contents, terminates the usually three-celled archicarp. Branches, one of which Woronin thinks may be the antheridium, grow up from the lower cells and cover in the, as yet, unbranched ascogonium. Owing to the density of the investing hyphae further development could not be traced.

In Lachnea stercorea, however, the ascogonium, before it is surrounded by hyphae, itself sends out a stout branch (Fig. 7), into which several nuclei pass (Fig. 8). This branch is cut off from the ascogonium by a wall on which granules may often be observed. It grows in length and becomes divided, first into two nearly equal cells, and eventually into four, five, or six cells (Fig. 9). Development probably takes place with some rapidity, for, though the unicellular stage was often found, the stage with two cells was only twice observed.

When fully developed this branch consists, as a rule, of five or six cells; those towards the archicarp are narrow, and, though always multinucleate, contain few nuclei. The terminal cell is considerably larger and its nuclei are much more numerous (Figs. 9, 10). In the early, unicellular stage the nuclei of the branch are quite similar to those of the ascogonium,

1 This term is used for the whole fertile branch other than the antheridium, while the term ascogonium is restricted to the reproductive cell or cells containing female nuclei (Blackman and Fraser (4)). 
from which it arises, but, as development proceeds, and the ascogonial nuclei increase in size and distinctness, no corresponding change is recognizable in those of the branch ; indeed, after a time, the nuclei of its lower cells are difficult to distinguish from granules.

This branch is not a precocious ascogenous hypha, for it never branches or develops further, and whereas the ascogenous hyphae become emptied as development proceeds, it retains its contents which degenerate in situ. Neither does there seem any reason to suppose it of use in conveying food-material to the ascogonium. Although multicellular, it corresponds in other features to the trichogyne of Pyronema confuens, and, since it shows evidence of a similar function, it may be conveniently designated by the same name.

Trichogyne. The position of the trichogyne in Lachnea stercorea is subject to a considerable amount of variation, sometimes, as in Figs. 9 and 13, it is almost terminal, but more often it is lateral (Figs. 12, 19), or is developed quite near the base of the ascogonium, and passes down almost parallel to the lower part of the archicarp (Fig. IO).

In some cases (Fig. 9) the trichogyne is fully developed, while the ascogonium is still perfectly free, and the sheath has only enveloped the lower cells of the archicarp; in others, however, where development seems scarcely more advanced, the sheath has already grown up about the ascogonium and trichogyne, though the tip of the latter frequently remains uncovered for a time (Fig. IO).

Antheridium. A considerable amount of material was examined in the hope of finding an antheridium arising, as in Pyronema, independently of the archicarp, but no structure approaching or becoming incorporated with the young ascocarp from without was ever observed, either in uncut material or in sections.

Often, however, at a stage when the sheath had completely surrounded the archicarp, a large, more or less empty sac was seen to be continuous with the terminal cell of the trichogyne, which at the same time was, in many cases, found to be densely packed with nuclei (Fig. I 2).

This sac, or antheridium, is not always well developed, and it was very seldom that a longitudinal section of a clearly defined example was obtained. One such, however, is shown in Fig. I3, where it is seen to be definitely continuous with the short trichogyne.

From such preparations it would appear that the antheridium is a unicellular structure, resembling in this respect that of Pyronema confluens, and both here and in oblique and transverse sections it can often be traced, more or less definitely towards the basal cell, or cell of the archicarp next below the ascogonium.

This cell, in L. stercorea, as in Humaria gramulata, differs somewhat from the lower cells of the archicarp. It has denser contents (Figs. Io, 
I 2, I3, \&c.), and its nuclei are intermediate in appearance between those of the ascogonium and of the ordinary gametophytic cells (Fig. 14). Such facts are suggestive of some special activity, and it is possibly significant, in this connexion, that the cell next below the ascogonium in Pyronema confluens, where the antheridium develops independently, differs in no way from the other supporting cells of the archicarp.

The antheridium contains a number of nuclei, but these either remain in situ (Fig. 13) or pass into the terminal cell of the trichogyne (Fig. 12), and they may be observed, often degenerating, but sometimes in an apparently healthy state, late in the development of the ascocarp. This is the case in the specimen shown in Fig. 18 , where the ascogonium is already almost empty. The limits of the antheridium and terminal cell of the trichogyne are here difficult to determine.

Often no clear indication of an antheridium could be found, and it would seem that, in some cases, an antheridium is not developed; but it is impossible to speak with certainty of an organ which is distinguished mainly by its shape and position, and which can be studied only in section.

Fertilization. In the specimen represented in Fig. Io the ascogonium is already giving off ascogenous hyphae, while the trichogyne is still exposed at the exterior of the sheath and no trace of an antheridium can be made out. Again, Fig. 13 shows a branching ascogonium, and a welldefined antheridium, in which, however, numerous nuclei may, at this late stage, be observed; and in Figs. 12 and 18 , although many male nuclei appear to have passed into the terminal cell of the trichogyne, they are cut off by its lower cells from the ascogonium.

Such cases are of frequent occurrence, and it would seem, therefore, that ordinary fertilization of the ascogonial by the antheridial nuclei does not normally occur. It is of course possible that this process may still occasionally take place, but among the nearly 300 ascogonia examined no satisfactory evidence of such a fertilization was found.

Another process, however, was frequently observed; the ascogonial, or female nuclei, were seen to fuse in pairs (Figs. 15, 16, 17) in a manner similar to that observed in Humaria granulata. The nuclei first fuse (Fig. I5), and the fusion of the nucleoli takes place later (Fig. 16).

The fusions occur at very various stages in the development of the ascocarp; the earliest seen (Fig. I7) was in the ascogonium shown in Fig. 9. In this case it is scarcely possible that antheridial nuclei have entered the ascogonium, and that the nuclei in process of fusion are male and female, for the trichogyne can be traced with great distinctness, and is entirely free either from antheridial or from sheath cells.

Fusions may also be observed when the ascogonium is nearly empty, but the majority probably take place at about the stage represented in Figs. 12 or 13 , and they occur in various parts of the ascogonium. 
In these particulars Lachnea stercorea resembles Humaria, whereas in Pyronema the fusions all take place at about the same time, and the paired nuclei are aggregated in the centre of the ascogonium. This aggregation is, no doubt, as Harper (16) suggests, a provision for the pairing of the male and female nuclei with the greatest certainty and dispatch, and it is obviously unnecessary in Humaria, where all the nuclei are presumably of equal value. The method of fusion in $L$. stercorea, therefore, may be regarded as additional evidence of the reduced nature of fertilization in this fungus.

The early contact stages of fusion cannot be recognized with certainty, but, apart from these, more than eighteen nuclear fusions were observed.

The number of nuclei in the ascogonium is very considerable, and seems to increase with the increasing size of that organ. In order to obtain some idea of the number of nuclei at various stages, the nuclei were counted, in a few cases in a series of sections of an ascogonium or trichogyne, with the following results:-

Young uncovered ascogonium, 267. Ascogonium, branching just begun, 536 .
Unicellular trichogyne, 37 .

Trichogyne of Fig. 9.

Terminal cell, 43 ; lower cells, 20. Trichogyne nearly covered by sheath.

Terminal cell, $3^{6}$; lower cells, 25 . Trichogyne of Fig. 12.

Terminal cell, 86 ; lower cells, 40.

The vacuolate antheridium, continuous with the trichogyne shown in Fig. I2, contained another twenty nuclei, and probably several of the closely packed nuclei in the terminal cell are also antheridial.

The above numbers are of course only roughly approximate, especially as the older ascogonia must contain several fusion nuclei; but it is evident from them that the nuclei of the ascogonium divide. Material was therefore fixed, at various hours of the day and night, in the hopes of finding such divisions. In a few cases indications of a spindle were seen, but the object was too small and too indistinct to be considered conclusive.

Sporophyte. Soon after the sheathing hyphae have grown up about the ascogonium branching begins. The ascogonial branches are of considerable size (Fig. I4) and often grow out freely beyond the investing cells. They contain numerous large, well-defined nuclei, the product, no doubt, of the fusions in the ascogonium.

Eventually the ascogonium becomes emptied of its contents, though a little cytoplasm and a few nuclei may be observed at quite a late stage (Fig. I9). The lower parts of the ascogenous hyphae also become emptied, and by the time that the spores are formed, both they and the ascogonium have disappeared. The contents of the trichogyne, as development pro- 
ceeds, become blackened and disintegrated (Fig. I9), and finally it also is lost. At a much earlier stage the antheridium has been obliterated.

The asci develop at the ends of the ascogenous hyphae by the peculiar process of bending over (Figs. 20, 2I) observed by Dangeard (7), Harper (15), and others. In the penultimate cell two nuclei fuse (Fig. 22) to form the nucleus of the growing ascus.

The further development of the asci was not specially studied as the object did not appear favourable. Their divisions show an intra-nuclear spindle, and finally eight spores are formed in each.

The peridium never closes completely, as in Humaria, or Ascobolus, across the top of the ascocarp, but forms a cup-shaped investment. Within is a tangle of vegetative hyphae, amongst which the branches of the ascogonium ramify, and from which the paraphyses eventually grow up. With regard to this character the position of $L$. stercorea is intermediate between that of the Pyronemaceae and such forms as Humaria gramulata. As in other members of the Pezizineae, a secondary mycelium grows downwards from the ascocarp and absorbs nourishment from the substratum.

\section{General Conclusions.}

It seems clear that Lachnea stercorea adds another to the list of sexually reduced Ascomycetes. Further, it cannot be regarded as parthenogenetic in the fullest sense, since the male gamete is replaced, as in Humaria gramulata (Blackman and Fraser (4)), and in certain of the Uredineae (Christman (5), Blackman and Fraser (3)), by a female nucleus.

Thus, with regard to its sexuality, Lachnea stercorea, in which the antheridium and trichogyne are present, though not functional, stands in a position intermediate between Pyronema confuens (Harper (17)) on the one hand and Humaria granulata on the other; and it differs very little from such 'parthenogenetic' specimens of Pyronema as were obtained in artificial culture by Van Tieghem (21) and by Dangeard (7). It is, indeed, as has been elsewhere suggested (Blackman and Fraser (4)), not improbable that further investigation may show that, in such cases also, the functionless male nuclei are replaced by female.

In Humaria granulata reduction has progressed a stage further; of the trichogyne, if such existed, there is no longer evidence, and the antheridium is also lost. In other particulars the structure and development of the archicarp, and indeed of the whole fruit, closely resemble those of $L$. stercorea.

A trichogyne is formed in a considerable number of the Ascomycetes hitherto investigated. 
It occurs in perhaps its simplest form in Boudiera (or Ascodesmis) (Claussen (6)), where it appears as a small upper portion cut off from the ascogonium, and it seems probable that the terminal cell of the coiled and septate archicarp in such forms as Aspergillus (De Bary (11)), Chaetomium (Oltmanns (19)), or Hypocopra (Nichols (18)), has or had a similar function.

In Pyronema the trichogyne, though unicellular, is better developed, and arises as a papilla from the growing ascogonium.

In Polystigma (Frank (13), Fisch (12)), in Gnomonia (Frank (14)) and in Collema (Baur (2)), Physcia (Darbishire (9)), and other Lichens, the trichogyne is multicellular, and this is also the case in Poronia punctata (Dawson (10)), where, however, the organ is not functional and degenerates early.

In these forms the terminal or receptive cell is enlarged, and to it the spermatia adhere. Polystigma and Gnomonia have not been found cytologically studied, but in the Lichens the cells of the trichogyne have been found to be uninucleate and connected together by broad cytoplasmic strands.

In the Laboulbeniaceae (Thaxter (20)), both unicellular and multicellular trichogynes occur, but these form a fairly complete series among themselves.

It will be seen that the trichogyne of Lachnea stercorea, consisting as it does of a series of coenocytic cells, the terminal of which is considerably larger than the others, is intermediate in structure between the trichogyne of Pyronema on the one hand, and that of such forms as Physcia and Collema on the other. It differs also from the latter in the fact that its constituent cells are not visibly connected by strands of cytoplasm ; such connexions may or may not have existed when the organ was functional.

L. stercorea, in the general structure of its ascocarp, in the organization of its large coenocytic ascogonium, and in the character of its male organ, resembles Pyronema much more closely than it does any of the Pyrenomycetes. But if $L$. stercorea be supposed to have arisen from such a form as Pyronema, it is difficult to imagine to what conditions the septation of the trichogyne was a response.

It may be that the close relation of the ascogonium and antheridium in L. stercorea was a late modification, and the multicellular structure of the trichogyne may have given it greater stability in reaching out towards a male organ developed at a distance. In Pyronema, however, the antheridium arises separately from the archicarp, and yet a unicellular trichogyne serves to connect the two.

On the other hand it has been held by Thaxter (20) and others that the Ascomycetes may be derived from the Red Algae, through some such 
forms as the Laboulbeniaceae, and that the Discomycetes may have been thence developed through Pyrenomycetous ancestors.

The multicellular ascogonium of Physcia has been found by Darbishire (9) to be practically a coenogamete, its uninucleate cells being connected by broad strands of protoplasm. In Ascobolus also, where the individual cells of the ascogonium are multinucleate, the walls between them are incompletely formed (Harper (16), and in Boudiera (Claussen (6)) they do not develop until after fertilization.

A series might thus be outlined, passing to Lachnea stercorea, where the walls of the ascogonium are not developed, and thence to Pyronema, where the now useless septa of the trichogyne are also lost. Humaria granulata would represent a side branch, passing out from the neighbourhood of Lachnea stercorea, possibly through L. scutellata (Woronin (22)).

A serious difficulty, however, in the way of any such series, whether it pass from the Pyronemaceae to the Laboulbeniaceae, or in the opposite direction, is the structure of the male organs. It may indeed be possible to relate the female organs of the group, but it is far more difficult, in the present state of our knowledge, to derive the spermogonium from the antheridium or vice versa, or to imagine stages by which the one may have replaced the other.

Further, it is of course perfectly possible that the multicellular trichogyne may have arisen separately in different groups of the Ascomycetes in response to similar needs.

\section{SUMmaRY.}

I. The archicarp of Lachnea stercorea consists of several cells and terminates in a large, multicellular ascogonium.

2. From the ascogonium a trichogyne, which is at first unicellular, but eventually consists of four, five, or six coenocytic cells, grows out. Its terminal cell is much larger than the others and may become continuous with the antheridium.

3. The antheridium, which is not always fully developed, is a unicellular coenocytic sac; its origin could not be traced with certainty.

4. The male nuclei do not reach the ascogonium, but fertilization of a reduced type occurs, the female nuclei fusing in pairs.

5. Ascogenous hyphae, into which the fused nuclei pass, grow out from the ascogonium, and asci are formed, by the usual method, at their tips.

6. Lachnea stercorea is intermediate, with regard to its sexuality, between Pyronema confuens on the one hand and Humaria gramulata on the other, and with regard to the organization of its trichogyne, between Pyronema and certain of the Pyrenomycetes.

October, I 906. 


\section{LIST OF PAPERS.}

1. BARker, B. T. P.: The Morphology and Development of the Ascocarp in Monascus. Ann. Bot., xvii, 1903, p. 167 .

2. BAur, E. : Zur Frage nach der Sexualität der Collemaceen. Ber. d. Deutsch. Bot. Gesellsch., xvi, I 898, p. 363 .

3. Blackman, V. H., and Fraser, H. C. I. : Further Studies on the Sexuality of the Uredineae. Ann. Bot., xx, I906, p. 35 .

4. in Humaria granulata, Quel. Proc. Roy. Soc., Ser. B, lxxvii, I906, p. 354.

5. Christman, A. H.: Sexual Reproduction of the Rusts, Bot. Gaz., xxxix, 1905, p. 267.

6. Claussen, P.: Zur Entwickelungsgeschichte der Ascomyceten. Boudiera. Bot. Zeit., lxiii, I 905 , P. I.

7. Dangeard, P. A.: Sur le Pyronema confuens, p. 30, and Apropos d'une lettre du Professeur Harper relative aux fusions nucléaires, p. 46 . Le Botaniste, $4^{\mathrm{me}}$ sér., I 894, p. 2 I.

8. : Recherches sur le développement du Périthèce chez les Ascomycètes. Le Botaniste, $9^{\mathrm{m} \bullet}$ sér., I904, p. 59 .

9. Darbishire, O. V.: Ueber die Apothecienentwickelung der Flechte Physcia pulverulenta (Schreb.), Nyl. Jahrb. f. wiss. Bot., xxxiv, I899, p. 329.

10. Dawson, M. : On the Biology of Poronia punctata (4). Ann. Bot., xiv, I900, p. 245.

11. De BAry, A.: Vergleichende Morphologie und Biologie der Pilze. Leipzig, I884.

12. FiscH, C.: Beiträge zur Entwickelungsgeschichte einiger Ascomyceten. Bot. Zeit., Jahrg. 40, I 882 , p. 850 .

13. Frank, B.: Ueber einige neue und weniger bekannte Pflanzenkrankheiten. Ber. d. Deutsch. Bot. Gesellsch., Bd. I, I883, p. $5^{8}$.

14. - Ueber Gnomonia erythrostoma, die Ursache, etc. Ber. d. Deutsch. Bot. Gesellsch., Bd. IV, I 886 , p. 200.

15. Harper, R. A. : Zur Kentniss der Kerntheilung und Sporenbildung im Ascus. Ber. d. Deutsch. Bot. Gesellsch., Bd. xiii, r895, p. 67 .

16. myceten. Jahrb. f. wiss. Bot., xxix, 1896, p. 655 .

17. - Sexual Reproduction in Pyronema confluens, \&c. Ann. Bot., xiv, I900, p. $3^{21}$.

18. Nichols, M. A. : The Morphology and Development of certain Pyrenomycetous Fungi. Bot. Gaz., xxii, ז896, p. 301 .

19. Oltmanns, F.: Ueber die Entwickelung der Perithecien in der Gattung Chaetomium. Bot. Zeit., xlv, I887, p. I92.

20. Thaxter, R. : Contributions towards a Monograph of the Laboulbeniaceae. Mem. Am. Acad. Arts and Sciences, xii, No. 3 .

21. Van Tieghem, Ph.: Culture et développement du Pyronema confuens. Bull. de la Soc. Bot. de France, xxxi, r884, p. 355 .

22. Woronin, M.: Zur Entwickelungsgeschichte des Ascobolus pulcherrimus. Beitr. zur Morph. und Physiol. der Pilze, Zweite Reihe, I866, p. I. 


\title{
EXPLANATION OF FIGURES IN PLATES XXIX AND XXX.
}

\author{
Illustrating Miss Fraser's paper on Lachnea stercorea.
}

Fig. I. (a) Fresh spore; (b) spore after treatment with dung extract at $38^{\circ} \mathrm{C}$.; (c) spore germinating in dung extract. $\times 500$.

Fig. 2. Spore, treated with $\mathrm{Na}_{2} \mathrm{CO}_{3}$, germinating in ascus. $\times 500$.

Fig. 3. Portion of mycelial hypha, showing nuclei and granules on transverse wall. $\times$ Izo0.

Fig. 4. Very young archicarp; fresh preparation. $\times 1000$.

Fig. 5. Rather older archicarp; fresh preparation. $\times 500$.

Fig. 6. Section of older archicarp before formation of trichogyne. $\times 600$.

Fig. 7. Archicarp with developing trichogyne. $\times 600$.

Fig. 8. Section of rather older archicarp, trichogyne still unicellular, but cut off from the ascogonium by a wall. $\times 1000$.

Fig. 9. Section of uncovered ascogonium with fully developed trichogyne. $\times 1000$.

Fig. Io. Longitudinal section of young ascocarp; ascogonium just beginning to branch, and trichogyne still exposed at exterior. $\times 600$.

Fig. I I. Transverse section of young ascocarp, showing branching ascogonium, and antheridium continuous with terminal cell of trichogyne. $\times 600$.

Fig. I2. Longitudinal section of young ascocarp, antheridium cut transversely and continuous with terminal cell of trichogyne, into which most of its nuclei have passed. $\quad \times 600$.

Fig. I3. Section of young ascocarp showing antheridium and archicarp cut longitudinally. The ascogonium is branching, and the antheridium is continuous with the terminal cell of the trichogyne, but contains degenerating nuclei. $\times 600$.

Fig. I4. Section showing parts of an ascogenous hypha, ascogonium and basal cell, and some vegetative cells. $\times$ I 300 .

Fig. I 5. Group of ascogonial nuclei, with a large fusion nucleus showing two nucleoli. $\quad \times 2700$.

Fig. 16. Fusion nucleus, showing nucleoli in process of fusion. $\times 2700$.

Fig. 17. Group of nuclei from a young ascogonium (Fig. 9), showing fusion of nucleoli. $\times 2700$.

Fig. I8. Trichogyne attached to a nearly empty ascogonium; its terminal cells continuous with an antheridium, and both contain nuclei. $\times$ rooo.

Fig. I9. Section through ascocarp at time of fusion in ascus; the archicarp is still visible, the ascogonium is nearly empty, as are the lower parts of the ascogenous hyphae, the contents of the trichogyne are blackened. $\times 300$.

Figs. 20-22. Stages in development of asci at ends of ascogenous hyphae. $\times \mathbf{I} 300$. 


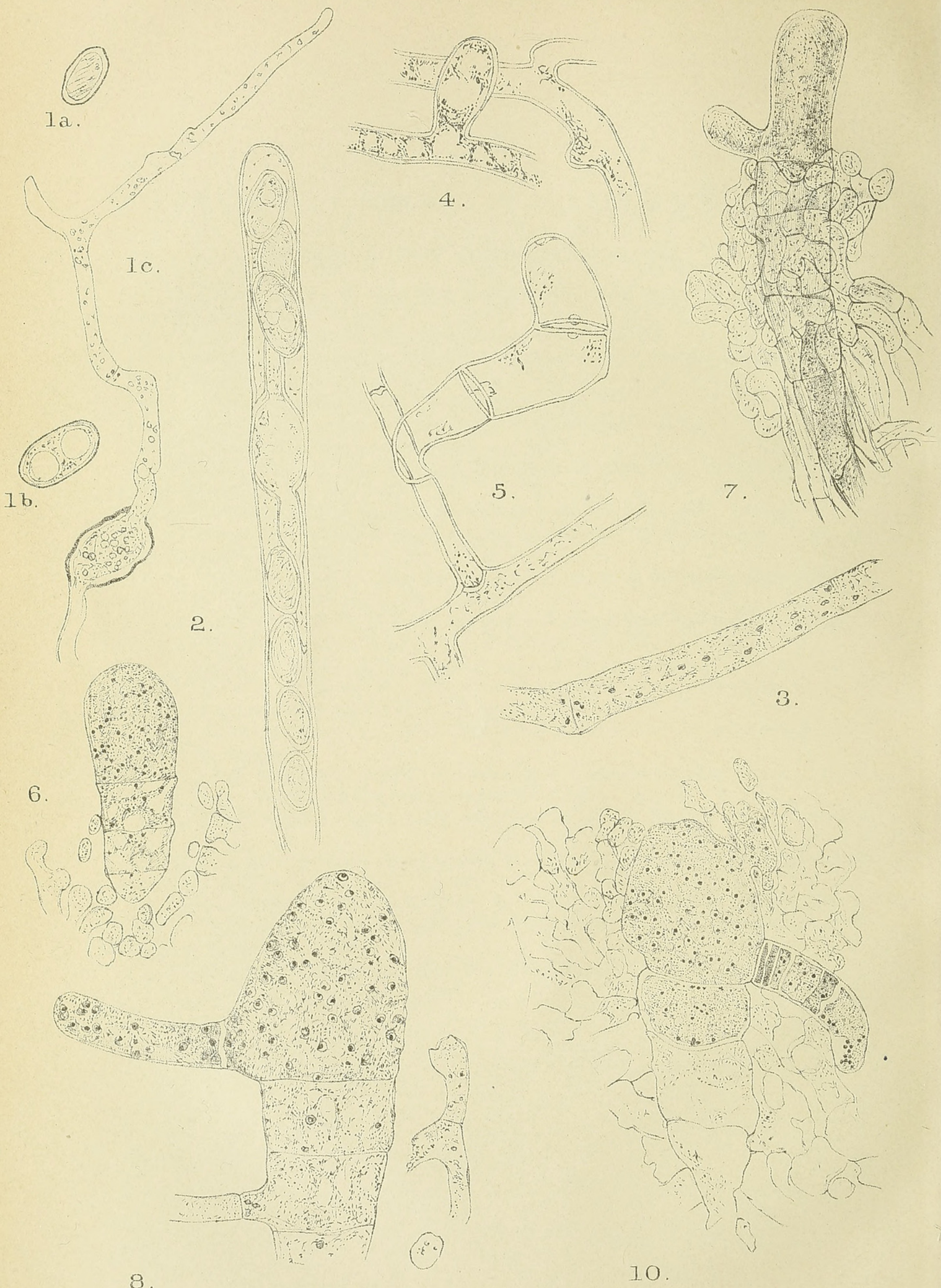


$61^{2} \div$ 2014

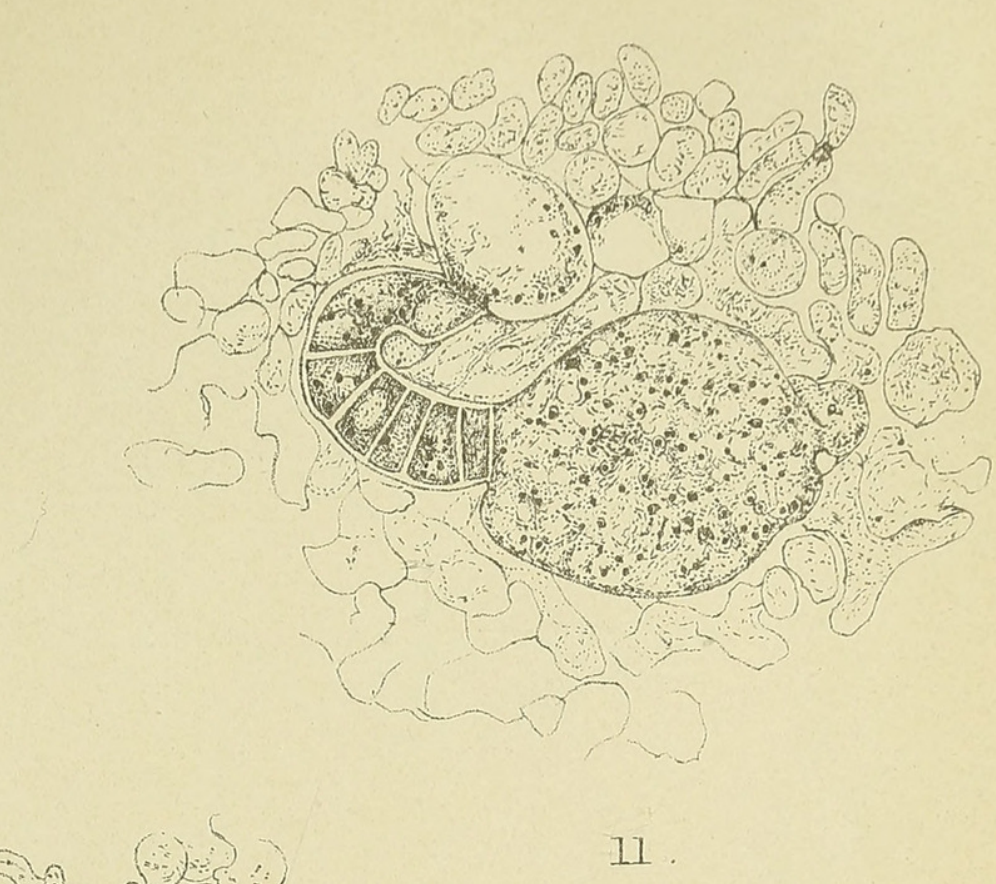

9.

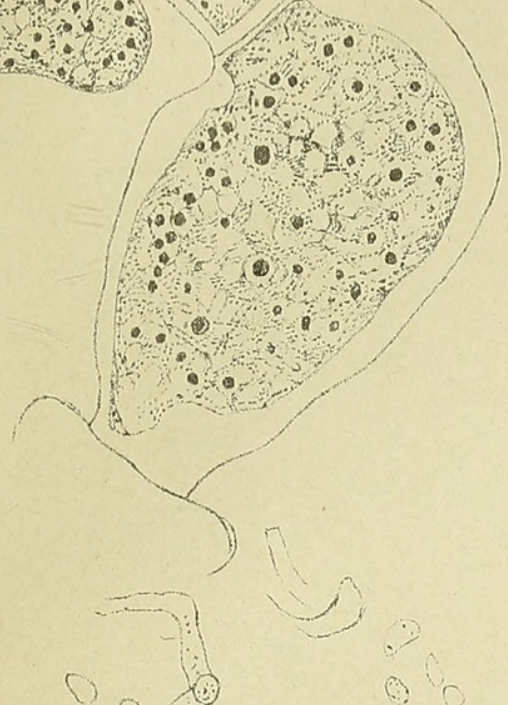

$0=0 \ldots$

A 20

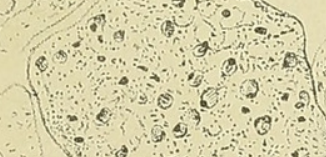

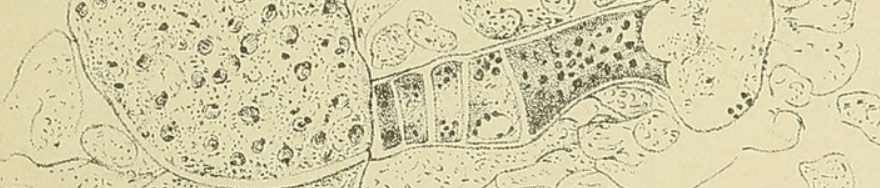
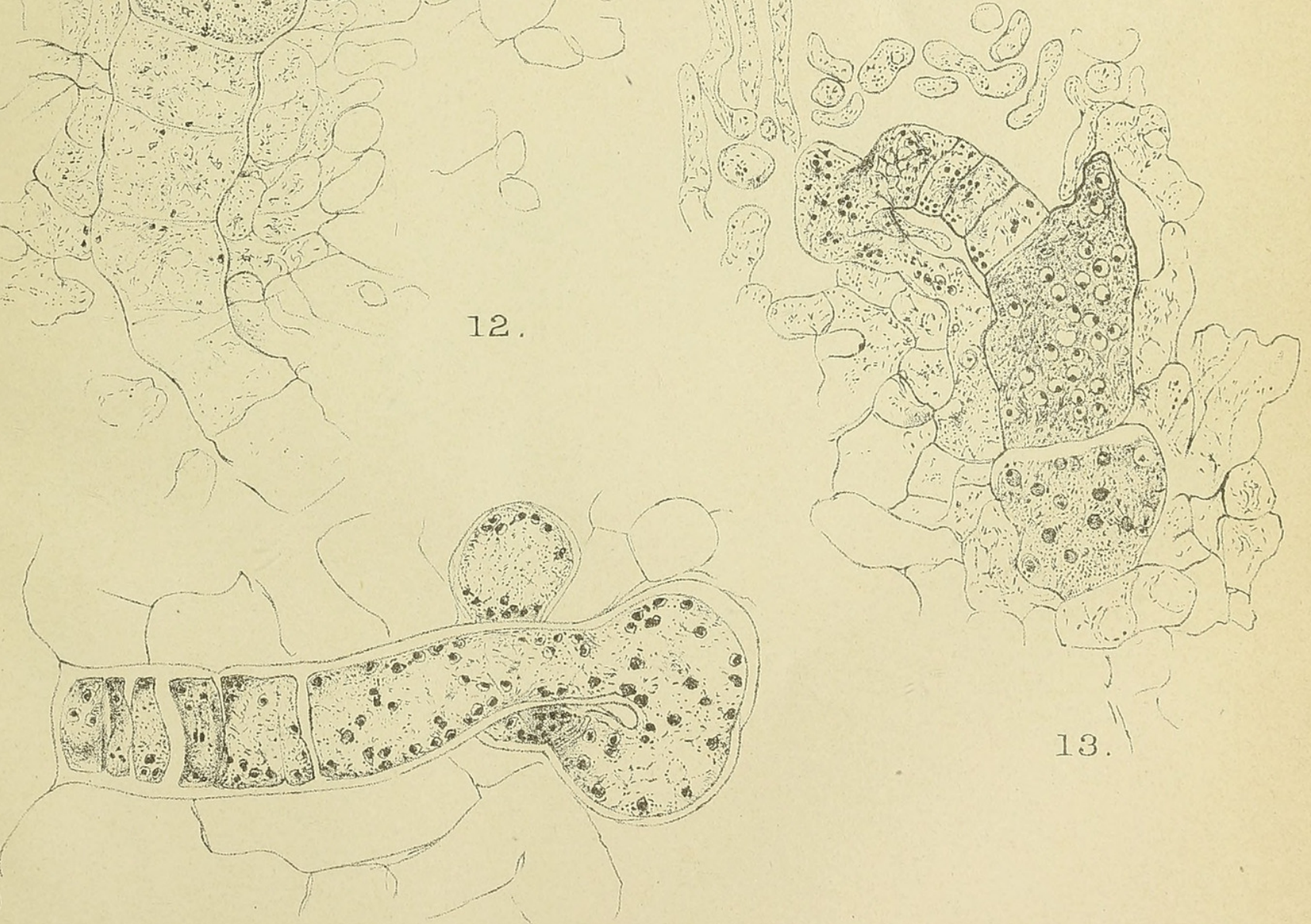

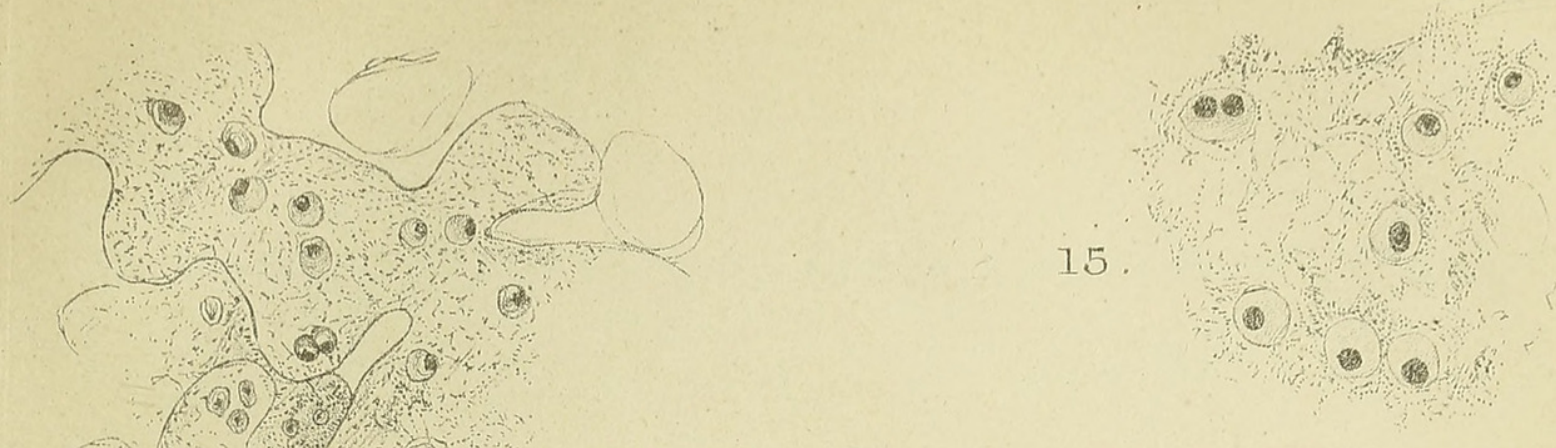

(2)
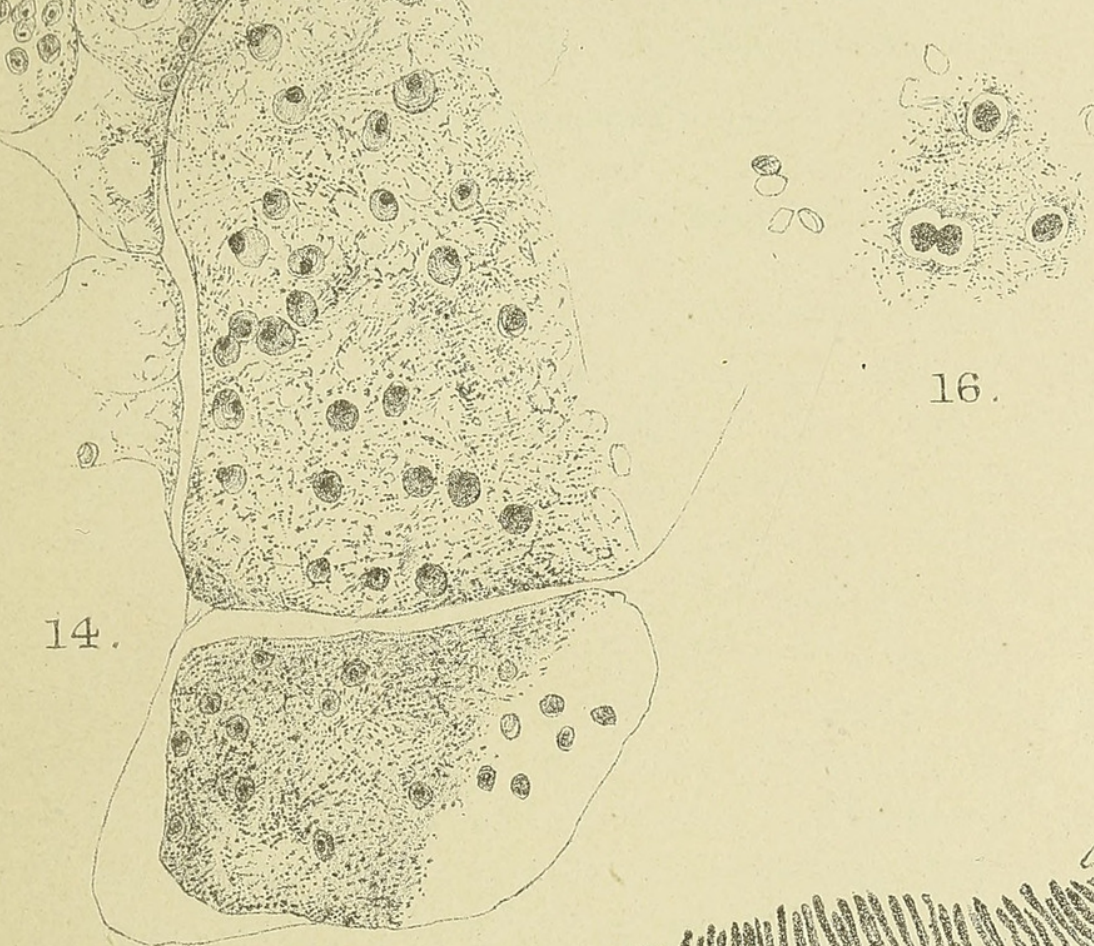

16

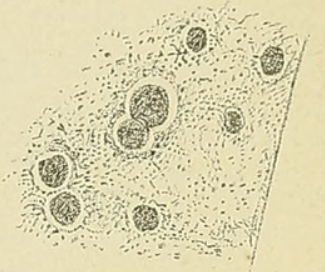

17.
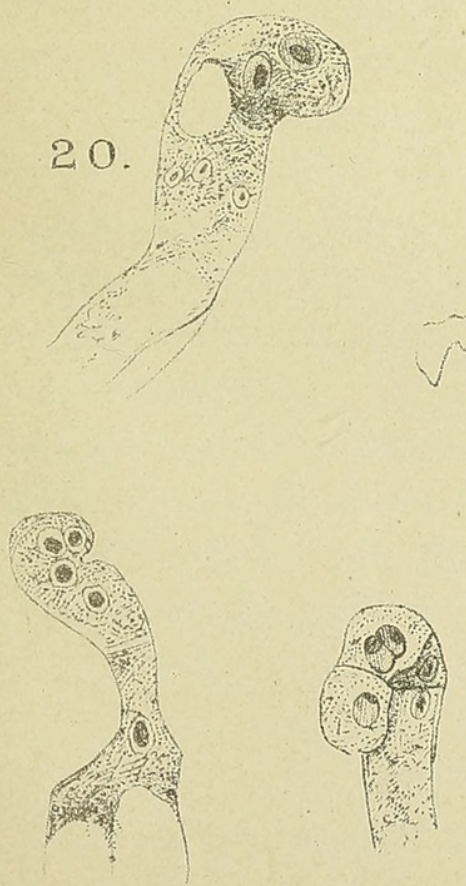

21.

22 


\section{$2 \mathrm{BHL}$ Biodiversity Heritage Library}

Gwynne-Vaughan, H. C. I. 1907. "On the sexuality and development of the ascocarp in Lachnea stercorea, Pers." Annals of botany 21, 349-360. https://doi.org/10.1093/oxfordjournals.aob.a089139.

View This Item Online: https://www.biodiversitylibrary.org/item/235747

DOI: https://doi.org/10.1093/oxfordjournals.aob.a089139

Permalink: https://www.biodiversitylibrary.org/partpdf/318878

\section{Holding Institution}

Smithsonian Libraries

\section{Sponsored by}

Biodiversity Heritage Library

\section{Copyright \& Reuse}

Copyright Status: Not in copyright. The BHL knows of no copyright restrictions on this item.

This document was created from content at the Biodiversity Heritage Library, the world's largest open access digital library for biodiversity literature and archives. Visit BHL at https://www.biodiversitylibrary.org. 